\title{
Pengaruh Prinsip-Prinsip Good Corporate Governance Pada Kualitas Informasi Keuangan Pdam Kabupaten Buleleng
}

\author{
Kadek Thasia Windisaptarianti Devi ${ }^{1}$ \\ Ni Made Dwi Ratnadi ${ }^{2}$ \\ ${ }^{1}$ Fakultas Ekonomi dan Bisnis Universitas Udayana (Unud), Bali, Indonesia \\ email: thasia.wd@gmail.com / Telp: +6282247370595 \\ ${ }^{2}$ Fakultas Ekonomi dan Bisnis Universitas Udayana (Unud), Bali, Indonesia
}

\begin{abstract}
ABSTRAK
Kualitas informasi keuangan dalam perusahaan penting diperhatikan, karena digunakan dalam pengambilan keputusan ekonomi dan mengetahui kondisi perusahaan. Perbedaan kepentingan antara pemilik dan pengelola Perusahaan Daerah Air Minum (PDAM) akan berdampak pada kualitas informasi keuangan yang dihasilkan, melalui penerapan prinsip Good Corporate Governance (GCG) diharapkan dapat mengurangi konflik tersebut. Tujuan penelitian yaitu untuk menguji secara empiris pengaruh prinsip GCG pada kualitas informasi keuangan PDAM Kabupaten Buleleng. Responden penelitian adalah karyawan bidang keuangan PDAM Kabupaten Buleleng yang berjumlah 46 responden. Penentuan sampel menggunakan metode nonprobability sampling dengan teknik purposive sampling. Metode pengumpulan data menggunakan kuesioner. Data dianalisis dengan regresi linier berganda.Hasil analisis menunjukkan prinsip transparancy, accountability, responsibility, independency dan fairness berpengaruh positif pada kualitas informasi keuangan PDAM Kabupaten Buleleng, sehingga disarankan agar pemerintah lebih memperhatikan penerapan prinsip GCG khususnya pada Badan Usaha Milik Daerah (BUMD) agar dapat meningkatkan nilai perusahaan dan kualitas informasi keuangan yang dihasilkan.
\end{abstract}

Kata kunci: Accountability, fairness, independency, responsibility, transparancy

\begin{abstract}
In company quality of financial information is important to note, because it used in economic decision making and to know the condition of the company. Good Corporate Governance need to be implemented in PDAM, because it can reduce agency conflicts between owners and manager.The purpose of this research is to know the influence of the application of GCG on financial information quality of PDAM Buleleng Regency. The respondents are employees of PDAM Kabupaten Buleleng, which are 46 respondents. Determination of sample using nonprobability sampling method with purposive sampling technique.Methods of data collection using questionnaires and using multiple linear regression analysis technique. The result of analysis shows that transparancy, accountability, responsibility, independency and fairness have positive effect on financial information quality of PDAM Buleleng Regency, in this case it is suggested that the government pay more attention to the implementation of GCG especially in BUMD.
\end{abstract}

Keywords: accountability, fairness, independency, responsibility, transparency

\section{PENDAHULUAN}

Kualitas informasi keuangan dalam perusahaan penting untuk diperhatikan karena bermanfaat untuk pengambilan keputusan ekonomi dan juga mengetahui kondisi 
keuangan perusahaan. Sejalan dengan Statement of Financial Accounting Concept (SFAC) No.2: qualitative characteristics of accounting information menjelaskan mengenai karakteristik kualitatif laporan keuangan berguna dalam menyakinkan bahwa informasi keuangan adalah bermanfaat dalam pengambilan keputusan ekonomi (FASB 1980). Karakteristik kualitatif utama dalam kualitas informasi euangan yaitu relavan serta reliabel, dimana kualitas relavan berkaitan dengan materialitas, sedangkan karakteristik selanjutnya mencangkup ketepatan waktu dan konsistensi. Kualitas informasi keuangan memiliki empat karakteristik pokok yaitu relavan, andal, dapat dibandingkan dan dapat dipahami (IAI, 2007). Tingkat relavan suatu informasi keuangan dapat dilihat dari kualitas informasi tersebut dalam mempengaruhi keputusan ekonomi para pemakai infomasi.

Selain itu informasi juga harus andal (reliable) yang artinya informasi tersebut disajikan secara jujur, dapat diverifikasi dan netralitas. Informasi keuangan akan lebih berguna jika dapat dibandingkan dengan periode sebelumnya atau entitas lain pada umumnya dan harus disajikan dengan baik agar dapat dipahami oleh pengguna. Dalam hal ini tata kelola perusahaan mengambil peranan dalam mempengaruhi kualitas informasi keuangan di perusahaan. Barrett (1997) menyatakan bahwa sebuah perusahaan dapat mengembangkan tata kelola perusahaan yang baik untuk memaksimalkan kualitas perusahaan.

Good Corporate Governance (GCG) merupakan perwujudan dari tata kelola perusahaan yang baik, berperan dalam mengatur serta mengendalikan perusahaan, sehingga mampu meningkatkan kepercayaan stakeholder dalam memperoleh informasi keuangan perusahaan yang disampaikan secara akurat, 
tepat waktu dan transparan(YPPMI, 2002).Organization for Economic Cooperation and Development (OECD) mendefinisikan corporate governancedigunakan untuk mengendalikan serta mengarahkan kegiatan dalam perusahaan (Chaarani, 2014).

Perusahaan dapat menyakinkan stakeholders dengan menjaga kualitas tata kelola perusahaan (Fathi, 2013). Untuk meningkatkan kualitas keuangan perusahaan perlu mengikuti pengelolaan yang diterapkan secara konsisten. Sehingga semua nilai yang dimiliki oleh pihak yang berkepentingan atas perusahaan dapat digunakan secara optimal dan menghasilkan pola hubungan ekonomis yang menguntungkan.Todorovicet al.(2012)menyatakan bahwa salah satu elemen kunci dalam meningkatkan kepercayaan investor, peningkatan pertumbuhan ekonomi serta peningkatan daya saing diwujudkan melalui corporate governance.Penerapan prinsip GCG akan memberi dampak pada kualitas perusahaan secara finansial maupun nonfinansial (Brown dan Caylor, 2004). Sebagai perusahaan yang memberikan pelayanan secara langsung kepada masyarakat (pelanggan)kualitas tata kelola maupun citraPeusahaan Daerah Air Minum (PDAM) Kabupaten Buleleng harus diperhatikan untuk keberlangsungan perusahaan.Corporate governance berperan dalam membangun kredibilitas dengan memastikan akuntabilitas, menjaga keefektifan serta keterbukaan penyampaian informasi yang nantinya mampu mendorong perusahaan memiliki kualitas yang baik (Mark, 2000).

Berdasarkan Surat Keputusan Menteri BUMN No.Kep 117/M-MBU/2002 Pasal 1 Tanggal 31 Juli 2002 yang telah disempurnakan menjadi Peraturan 
Menteri Negara BUMN Nomor: Per-01/MBU/2011, menjelaskan penerapan good corporate governance dalam perusahaan mampu meningkatkan nilai pemegang saham dan memberikan perhatian terhadap kepentingan stakeholder dalam jangka waktu yang panjang dengan berlandaskan peraturan perundangan serta nilai-nilai etika. PDAM adalah salah satu Badan Usaha Milik Daerah (BUMD) yang bertanggung jawab dalam mengelola sistem penyediaan air bersih dan memberi pelayanan kepada konsumen. PDAM juga berperan dalam melaksanakan pembangunan daerah dan nasional melalui penyediaan air bersih dan sehat serta memberikan pelayanan secara jujur dan transparan. Sehingga PDAM harus menerapkan prinsip ekonomi yang sehat dalam penyelenggaraan maupun sistem tata kelola perusahaan.

Pada tahun 2006 Komite Nasional Kebijakan Governance (KNKG) menerbitkan pedoman pelaksanaan good corporate governance sebagai dorongan agar perusahaan mampu menciptakan sistem tata kelola yang sehat. KNKG (2006:5) menyebutkan lima prinsip GCG yaitu transparancy (keterbukaan informasi), accountability (akuntabilitas), responsibility (pertanggungjawaban), independency (kemandirian) dan fairness (kesetaraan dan kewajaran). Oliver (1995) menyatakan bahwacorporate governance muncul dalam organisasi disebabkan karena adanya masalah agensi atau konflik kepentingan yang melibatkan anggota organisasi. Hindistari (2016), dalam hasil penelitiannya menyatakan bahwa prinsip-prinsip GCG berpengaruh positif pada kinerja Bank Perkreditan Rakyat (BPR) di Kabupaten Gianyar. Noviolanita (2015) menyimpulkan bahwa penerapan prinsip-prinsip GCG berpengaruh positif pada 
kualitas laporan keuangan PT PLN (Persero) distribusi Jawa Barat dan Banten. Sedangkan Mahaendrayasa (2017) mengatakan prinsip transparancy dan responsibility tidak berpengaruh terhadap kinerja keuangan LPD di Kota Denpasar.

Penelitian mengenai penerapan good corporate governance terhadap kinerja keuangan telah banyak yang meneliti, namun masih sedikit yang menjadikan PDAM sebagai objek penelitian. Berdasarkan pengetahuan peneliti, masih jarang bahkan dapat dikatakan belum ada yang meneliti tentang pengaruh penerapan prinsip-prinsip good corporate governance di PDAM Kabupaten Buleleng. Penelitian sebelumnya hanya meneliti mengenai pengukuran kinerja berbasis balanced scorecard. Dengan pertimbangan tersebut, peneliti ingin membuktikan pengaruh kelima prinsip good corporate governanceyaitu transparancy, accountability, responsibility, indenpendency dan fairnesspada persepsi kualitas informasi keuangan PDAM Kabupaten Buleleng.

Tujuan penelitian ini yaitu menguji secara empiris pengaruh penerapan prinsip good corporate governance pada kualitas informasi keuangan PDAM Kabupaten Buleleng. Manfaat penelitian yaitu mengkonfirmasi teori keagenan dan teori stewardshipdalam menjelaskan pengaruh penerapan prinsip good corporate governance padakualitas informasi keuangan.

Teori keagenan merupakan hubungan atau kontrak antara principal dan agent(Anthony dan Govindarajan, 2011:10). Principal akan mempekerjakan agent dalam melakukan tugas untuk kepentingan principal, termasuk pengambilan keputusan dari principal kepada agent. Teori keagenan memaparkan adanya 
pemisahan hak milik perusahaan dan pertanggungjawaban atas pembuatan keputusan (Jensen dan Meckling, 1976).

Hubungan keagenan dapat menimbulkan permasalahan antara pemilik dan agen karena adanya perbedaan kepentingan. Tidak dipungkiri dalam suatu perusahaan terjadi konflik antara pemilik dan pengelola, karena informasi yang diberikan kepada pemilik dari pengelola kadang tidak sesuai (Araujo et al., 2013). Pemilik perusahaan cenderung ingin memperoleh keuntungan yang maksimal dengan biaya yang seefisien mungkin. Terdapat tiga asumsi sifat manusia yang digunakan dalam teori keagenan (agency theory) antara lain umumnya manusia mementingkan diri sendiri, kemampuan berpikir manusia tentang kehidupan di masa depanmasih terbatas serta kecenderungan dalam menghindari risiko (Eisenhardt, 1989).Dari ketiga sifat manusia tersebut permasalahan mengenai perbedaan kepentingan akan timbul dalam perusahaan karena dalam hal ini pemilik (prinsipal) tidak selalu mengawasi kegiatan manajeman (agen) untuk memastikan bahwa manajeman bekerja sesuai dengan perintah pemilik. Peni et al. (2013) menyatakan bahwa good corporate governance dapat mengatasi masalah yang terjadi antara agen dan prinsipal yang disebabkan karena kurangnya perhatian perusahaan terhadap tata kelola perusahaan yang masih lemah. Tata kelola perusahaan di Indonesia masih lemah disebabkan karena peraturan perundangan yang mengatur mengenai sistem tata kelola perusahaan kurang tegas terutama mengenai pelanggaran yang dilakukan oleh pengelola perusahaan. Untuk mengurangi dampak dari hubungan keagenan dalam hal ini disebut asimetri 
informasi, dapat dilakukan pengedalian internal dengan menerapkan corporate governance(Clemente dan Labat, 2009).

Teori stewardshipmenjelaskan bahwa pihak manajemen sebagai steward memiliki dasar psikologi dan sosiologi untuk bertindak sesuai dengan keinginan prinsipal, selain itu stewardakan berusaha untuk mencapai sasaran organisasinya sehingga stewardtidak akan meninggalkan organisasi(Riyadi, 2014). Teori ini mengasumsikan hubungan yang kuat antara kesuksesan organisasi dengan kepuasan pemilik, karena kepercayaan merupakan kunci dalam teori ini. Wijaya dan Sudarma (2015) menyatakan bahwa steward sebagai pihak yang diberi kepercayaan sedangkan prinsipal sebagai pihak yang memberi kepercayaan. Teori ini didesain bagi para peneliti untuk menguji situasi dimana para pihak manajemen pada perusahaan sebagai pelayan dapat termotivasi untuk bertindak dengan cara terbaik kepada prinsipalnya.

Teori keagenan menunjukkan bahwa agen lebih banyak tahu tentang informasi perusahaan, maka untuk mengindari terjadinya asimetri informasi diperlukan keterbukaan informasi atau transparansi. Keterbukaan (transparancy) diperlukan untuk menjaga objektivitas dalam menjalankan bisnis dan memberikan keyakinan dari agen kepada prinsipal. Dalam suatu perusahaan transparancy penting karena berhubungan dengan informasi keuangan maupun non keuangan yang akan disajikan oleh agen kepada prinsipal. Haque (2008) menyatakan bahwa membuat informasi keuangan maupun non keuangan penting bagi perusahaan agar dapat mempermudah orang luar dalam membuat keputusan melalui informasi yang disajikan. Penelitian yang dilakukan oleh Taufan (2016), menyatakan bahwa 
variabel transparansi berpengaruh signifikan terhadap kualitas laporan keuangan daerah Bandung.

$\mathrm{H}_{1}$ : Transparancy berpengaruh positif pada kualitas informasi keuangan PDAM Kabupaten Buleleng.

Perusahaan yang accountable memiliki ciri-ciri, yaitu mampu menyajikan informasi penyelenggaraan secara terbuka, cepat, tepat kepada masyarakat, mampu memberikan pelayanan yang memuaskan bagi publik, mampu menjelaskan dan mempertanggungjawabkan setiap kebijakan publik secara proporsional dan mempertanggungjawabkan setiap kebijakan, serta adanya sarana bagi publik untuk menilai kinerja pemerintah. Akuntabilitas memberikan peranan dalam menjelaskan kepada karyawan perusahaan mengenai rincian tugas dan tanggung jawab, sehingga akan memberikan dampak yang berkesinambungan atas operasional perusahaan yang nantinya berpengaruh pada hasil informasi bagi perusahaan. Hayati et al. (2009) menyatakan bahwa sektor keuangan adalah salah satu sektor yang memberi pengaruh dalam operasional perusahaan. Dengan menerapkan akuntabilitas dalam perusahaan diharapkan dapat meningkatkan kepercayaan masyarakat terhadap kualitas perusahaan (Onuorah dan Appah, 2012). Hasil penelitian Taufan (2016)menunjukkan bahwa akuntabilitas berpengaruh signifikan terhadap kualitas laporan keuangan daerah Bandung.

$\mathrm{H}_{2}$ : Accountability berpengaruh positif pada kualitas informasi keuangan PDAM Kabupaten Buleleng.

Pertanggungjawaban perusahaan merupakan kesesuaian tata kelola perusahaan pada peraturan perundangan serta prinsip-prinsip perusahaan yang sehat. Dalam aktivitasnya perusahaan harus mampu memastikan bahwa seluruh 
organ perusahaan patuh pada peraturan perusahaan maupun peraturan perundangan, sehingga perusahaan akan bertanggung jawab atas informasi keuangan perusahaan. Berdasarkan teori stewardshipkepentingan perusahaan merupakan sasaran utama yang harus dicapai, maka dari itu manajer hanya fokus pada tujuan perusahaan(Riyadi dan Agung, 2014).

Selaku pihak yang diberi kepercayaan oleh principal, manajer akan cenderung merasa memiliki tanggung jawab atas informasi keuangan perusahaan. Noviolanita (2015) pada hasil penelitiannya yaitu penerapan prinsip-prinsip GCGberpengaruh positif pada kualitas laporan keuangan PT PLN (Persero) distribusi Jawa Barat dan Banten.

$\mathrm{H}_{3}$ : Responsibility berpengaruh positif pada kualitas informasi keuangan PDAM Kabupaten Buleleng.

Independensi adalah salah satu bentuk pengambilan keputusan dengan objektif, sehingga pengelolaan perusaahaan harus dilakukan secara independen yaitu tidak saling mempengaruhi maupun saling mendominasi. Perusahaan dapat beroperasi dengan baik apabila seluruh anggota perusahaan mengutamakan kepentingan perusahaan. Sesuai dengan teori stewardship, dimana kepentingan bersama dijadikan dasar dari tindakan manajer. Manajer cenderung bertindak sesuai keinginan principal dan berusaha mencapai sasaran organisasinya. Sehingga manajer tidak mudah terpengaruh dengan kepentingan-kepentingan lainnya karena manajer berusaha sebaik mungkin dalam menyampaikan informasi keuangan demi sasaran atau tujuan perusahaannya.

$\mathrm{H}_{4}$ : Independency berpengaruh positif pada kualitas informasi keuangan PDAM Kabupaten Buleleng. 
Perusahaan dalam melakukan aktivitas operasional harus memberikan perhatian yang berhubungan mengenai kepentingan para stakeholderberdasarkan pada prinsip kesetaraan dan kewajaran (fairness). Dalam hal ini perusahaan diharuskan agar memberikan perlakuan dan kesempatan yang sama kepada seluruh karyawan dalam penyampaian pendapat bagi kepentingan perusahaan utamanya tentang informasi keuangan.

Hubungan antara agen dan principal harus saling memberi umpan balik, sehingga agen akan memberikan informasi keuangan sesuai dengan apa yang diharapkan principal. Untuk itu kesetaraan dalam perusahaan penting. Noviolanita (2015) pada hasil penelitiannya yaitu penerapan prinsip-prinsip GCG berpengaruh positif pada kualitas laporan keuangan PT PLN (Persero) distribusi Jawa Barat dan Banten.

$\mathrm{H}_{5}$ : Fairness berpengaruh positif pada kualitas informasi keuangan PDAM Kabupaten Buleleng.

\section{METODE PENELITIAN}

Lokasi penelitian adalah PDAM Kabupaten Buleleng. Objek penelitian ini yaitu kualitas informasi keuangan pada PDAM Kabupaten Buleleng yang dijelaskan dengan penerapan prinsip good corporate governance.Populasi pada penelitian ini adalah seluruh karyawan pada kantor pusat dan kantor cabang /unit PDAM Kabupaten Buleleng yang berjumlah 258 orang. Penentuan sampel menggunakan metode nonprobability sampling dengan teknik purposive sampling, adapun kriteria sampel yaitu karyawan yang bekerja pada bidang keuangan yang terdiri dari karyawan bagian kas, karyawan bagian penagihan, karyawan bagian perencanaan keuangan, karyawan bagian akuntansi serta karyawan bagian 
administrasi keuangan. Data yang dianalisis adalah data primer yang berupa jawaban dari responden atas kuesioner yang disebarkan. Kuesioner menggunakan skala likert lima poin. Sebelum kuesioner disebarkantelah diuji validitas dan realibilitasnya.

Variabel transparancy(keterbukaan) diukur dengan empat indikator yaitu kebijakan perusahaan yang dikomunikasikan kepada pemangku kepentingan, kewajiban perusahaan dalam menyajikan informasi secara jelas, tepat waktu, transparan dan dapat dibandingkan, perusahaan menyusun,mengaudit serta menyajikan informasi lapporan keuangan sesuai standar akuntansi dan keterbukaan informasi tidak mengurangi dalam menjaga kerahasiaan perusahaan.

Variabel accountability (akuntabilitas) diukur menggunakan lima indikator yaitu rincian tugas serta tanggung jawab perusahaan ditetapkan dengan jelas dan sejalan dengan tujuan perusahaan,seluruh karyawan memiliki kemampuan yang sesuai dengan tanggung jawab, tugas dan perannya dalam melaksanakan GCG, pengelolaan internal perusahaan dikendalikan secara efektif, pengukuran kinerja diterapkan secara konsisten sesuai dengan nilai-nilai perusahaan dan seluruh karyawan dalam melaksanakan tugas serta tanggung jawabnya harus berpegangan pada etika bisnis.

Variabel responsibility (pertanggungjawaban) diukur dengan tiga indikatoryaitu pelaksanaan tanggung jawab sosial terhadap masyarakat serta lingkungan disekitar perusahaan telah dilaksanakan secara memadai, perusahaan memastikan setiap karyawannya patuh pada peraturan perusahaan maupun 
peraturan perundangan dan perusahaan dalam melaksanakan aktivitasnya sesuai dengan prinsip ekonomi yang sehat.

Variabel independency (kemandirian) diukur dengan empat indikator yaitu masing-masing organ perusahaan menghindari terjadinya dominasi oleh pihak manapun, tidak terpengaruh oleh kepentingan tertentu, bebas dari benturan kepentingan dan dari segala pengaruh dan tekanan, perusahaan dalam menetapkan jabatan penting dilakukan secara independen, dalam aktivitasnya perusahaan tidak saling melempar tanggung jawab antara satu pihak dengan pihak lainnya sehingga dapat mewujudkan sistem pengendalian internal yang efektif dan perusahaan dalam pengambilan keputusan dilakukan dengan objektif yaitu tidak adanya tekanan dari pihak manapun.

Variabel fairness (kesetaraan dan kewajaran) diukur dengan tiga indikator yaitu seluruh pemangku kepentingan maupun karyawan diberikan kesempatan yang sama dalam menyampaikan pendapat untuk kepentingan perusahaan, kesetaraan dan kewajaran yang diberikan kepada pemangku kepentingan maupun karyawan telah disesuaikan dengan kontribusi yang diberikan kepada perusahaan dan perusahaan memberikan kesempatan yang sama baik dalam hal penerimaan karyawan, berkarir serta pelaksanaan tugas secara adil tanpa memperhatikan agama, suku, ras mapupun gender.

Variabel kualitas informasi keuangan yang dimaksud dalam penelitian ini merupakan persepsi responden atas kualitas informasi keuangan yang telah disajikan atau dihasilkan oleh perusahaan, berguna dalam pengambilan keputusan 
di masa kini maupun masa depan. Kualitas informasi keuangan terdiri dari empat indikator, yaitu relavan, andal, dapat dibandingkan dan dapat dipahami.

Penelitian menggunakan analisis regresi linier berganda yaitu untuk menguji hubungan antara dua atau lebih variabel. Adapun rumus analisis regresi linier berganda untuk variabel penelitian disajikan sebagai berikut.

$$
Y=\alpha+\beta_{1} X_{1}+\beta_{2} X_{2}+\beta_{3} X_{3}+\beta_{4} X_{4}+\beta_{5} X_{5}+\varepsilon
$$

Keterangan:

\begin{tabular}{|c|c|}
\hline Y & $=$ Persepsi kualitas informasi keuangan \\
\hline$\alpha$ & $=$ Konstanta \\
\hline$\beta_{1,2,3,4,5}$ & $=$ Koefisien regresi dari variabel independen \\
\hline$\varepsilon$ & $=$ Error term \\
\hline $\mathrm{X}_{1}$ & $=$ Transparancy \\
\hline $\mathrm{X}_{2}$ & $=$ Accountability \\
\hline $\mathrm{X}_{3}$ & $=$ Responsibility \\
\hline$X_{4}$ & $=$ Independency \\
\hline $\mathrm{X}_{5}$ & $=$ Fairness \\
\hline
\end{tabular}

Sebelum menganalisis data dengan menggunakan regresi linear berganda, harus terlebih dahulu memenuhi uji asumsi klasik. Adapun uji asumsi klasik yang dilakukan terdiri dari uji normalitas, uji multikolinearitas dan uji heterokedastisitas.

\section{HASIL DAN PEMBAHASAN}

Kuesioner penelitian ini diadopsi dari penelitian yang dilakukan Sari (2014), penelitian tersebut menghasilkan tingkat persentase validitas dan reliabilitas instrumen sebesar 85,59 persen, dengan pertimbangan tersebut peneliti secara langsung menggunakan 30 responden dari karyawan bidang keuangan PDAM Kabupaten Buleleng sebagai sampel awal bahwa alat ukur atau instrumen yang digunakan sesuai untuk penelitian. Secara keseluruhan jumlah kuesioner yang layak digunakan adalah 46 kuesioner. Hasil uji menunjukkan bahwa nilai 
koefisien korelasi lebih besar dari 0,3 sehingga dapat disimpulkan seluruh indikator pertanyaan memenuhi syarat validitas data. Nilai cronbach's alpha masing-masing variabel memiliki nilai lebih besar dari 0,6 sehingga dapat disimpulkan seluruh pertanyaan adalah reliabel. Deskripsi tiap-tiap variabel penelitian disajikan pada Tabel 1 .

Tabel 1.

Hasil Statistik Deskriptif

\begin{tabular}{lrrrrc}
\hline \multicolumn{1}{c}{ Variabel } & N & Min. & Max. & Mean & $\begin{array}{c}\text { Std. } \\
\text { Deviasi }\end{array}$ \\
\hline Transparancy $\left(\mathrm{X}_{1}\right)$ & 46 & 2,25 & 5,00 & 4,07 & 0,58 \\
Accountability $\left(\mathrm{X}_{2}\right)$ & 46 & 2,40 & 5,00 & 4,06 & 0,48 \\
Responsibility $\left(\mathrm{X}_{3}\right)$ & 46 & 2,33 & 5,00 & 4,02 & 0,58 \\
Independency $\left(\mathrm{X}_{4}\right)$ & 46 & 3,00 & 5,00 & 4,18 & 0,42 \\
Fairness $\left(\mathrm{X}_{5}\right)$ & 46 & 2,67 & 5,00 & 4,05 & 0,63 \\
Persepsi Kualitas Informasi & 46 & 3,29 & 5,00 & 4,13 & 0,37 \\
Keuangan (Y) & & & & &
\end{tabular}

Berdasarkan Tabel 1 variabel transparancy (keterbukaan) memiliki ratarata nilai sebesar 4,07 yang berarti bahwa responden cenderungsetuju atas indikator variabel transparancyyaitu komunikasi mengenai kebijakan perusahaan, keterbukaan informasi, tepat waktu, jelas dan dapat diperbandingkan.

Variabel accountability(akuntabilitas) memiliki rata-rata nilai sebesar 4,06 yang berarti bahwa responden cenderung setuju atas indikator variabel accountabilityyaitu penetapan rincian tugas yang jelas, kesesuaian kompetensi karyawan dengan tugas serta perannya dalam pelaksanaan GCG, pelaksanaan sistem pengendalian internal yang efektif dan ukuran kinerja perusahaan yang konsisten.

Variabel responsibility(pertanggungjawaban) memiliki rata-rata nilai sebesar 4,02 yang berarti responden cenderung setuju atas indikator variabel responsibilityyaitu pelaksanaan tanggung jawab sosial terhadap masyarakat dan 
lingkungan, kepatuhan perusahaan pada peraturan perundangan dan pelaksanaan prinsip ekonomi yang sehat.

Variabel independency(kemadirian) memiliki rata-rata nilai sebesar 4,18 yang berarti responden cenderung setuju atas indikator variabel independencyyaitu menghindari dominasi oleh pihak manapun, tidak terpengaruh oleh kepentingan tertentu, bebas dari benturan kepentingan dan penetapan jabatan penting dilakukan secara independen.

Variabel fairness(kesetaraan dan kewajaran) memiliki rata-rata nilai sebesar 4,05 yang berarti responden cenderung setuju atas indikator variabel fairnessyaitu kesempatan memberikan masukan dan pendapat, kesetaraan perlakuan dalam perusahaan dan penerimaan karyawan.

Variabel kualitas informasi keuangan memiliki rata-rata nilai sebesar 4,13 yang berarti responden cenderung setuju atas indikator variabel kualitas informasi keuangan yaitu relavan, andal, dapat dibandingkan dan dapat dipahami. Sebelum dilakukan analisis regresi linear berganda, terlebih dahulu dilakukan uji asumsi klasik. Hasil uji asumsi klasik disajikan pada Tabel 2.

Tabel 2.

Hasil Uji Asumsi Klasik

\begin{tabular}{lcccc}
\hline \multirow{1}{*}{ Model } & \multirow{2}{*}{$\begin{array}{c}c \\
\text { Uji }\end{array}$} & \multicolumn{2}{c}{ Multikolineritas } & \multicolumn{2}{c}{ Uji } \\
& Normalitas & Heterokedastisitas \\
& & Tolerance & VIF & Sig. \\
\hline Transparancy $\left(\mathrm{X}_{1}\right)$ & & 0,51 & 1,98 & 0,47 \\
Accountability $\left(\mathrm{X}_{2}\right)$ & & 0,47 & 2,14 & 0,95 \\
Responsibility $\left(\mathrm{X}_{3}\right)$ & & 0,54 & 1,85 & 0,20 \\
Independency $\left(\mathrm{X}_{4}\right)$ & & 0,84 & 1,19 & 0,09 \\
Fairness $\left(\mathrm{X}_{5}\right)$ & & 0,62 & 1,62 & 0,43 \\
Asym. Sig & 0,74 & & & \\
\hline
\end{tabular}

Sumber: Data diolah, 2017 
Berdasarkan Tabel 2, hasil uji normalitas menunjukkan nilai asym. sigsebesar 0,74 lebih besar dari 0,05 artinya seluruh variabel pada penelitian berdistribusi normal.Hasil dari uji multikolinearitas menunjukkan bahwa tiap-tiap variabel memiliki nilai tolerance lebih dari 0,10 dan nilai VIF lebih kecil dari 10 ini berarti tidak ada multikol antara variabel bebas dalam model regresi. Hasil uji heterokedastisitas menunjukkan nilai signifikansi variabeltransparancy, accountability, responsibility, independency dan fairness lebih besar dari 0,05 ini berarti model regresi bebas dari gejala heterokedastisitas. Pada Tabel 3 disajikan hasil uji analisis regresi linear berganda.

Tabel 3.

Hasil Uji Analisis Regresi Linear Berganda

\begin{tabular}{|c|c|c|c|c|c|c|}
\hline \multirow{2}{*}{ Model } & & \multicolumn{2}{|c|}{$\begin{array}{l}\text { Unstandardized } \\
\text { Coefficients }\end{array}$} & \multirow{2}{*}{$\begin{array}{c}\text { Standardized } \\
\text { Coefficients } \\
\text { Beta }\end{array}$} & \multirow{2}{*}{$t$} & \multirow{2}{*}{ Sig. } \\
\hline & & B & $\begin{array}{c}\text { Std. } \\
\text { Error }\end{array}$ & & & \\
\hline (Constant) & & 0,36 & 0,28 & & 1,28 & 0,21 \\
\hline Transparancy $\left(\mathrm{X}_{1}\right)$ & & 0,18 & 0,05 & 0,29 & 3,41 & 0,00 \\
\hline Accountability $\left(\mathrm{X}_{2}\right)$ & & 0,27 & 0,07 & 0,35 & 3,99 & 0,00 \\
\hline Responsibility $\left(\mathrm{X}_{3}\right)$ & & 0,12 & 0,05 & 0,19 & 2,36 & 0,02 \\
\hline Independency $\left(\mathrm{X}_{4}\right)$ & & 0,27 & 0,06 & 0,27 & 4,10 & 0,00 \\
\hline Fairness $\left(\mathrm{X}_{5}\right)$ & & 0,11 & 0,05 & 0,19 & 2,52 & 0,02 \\
\hline Adjusted $R^{2}$ & 0,84 & & & & & \\
\hline F Hitung & 46,62 & & & & & \\
\hline Sig. F & 0,00 & & & & & \\
\hline
\end{tabular}

Berdasarkan hasil uji regresi linear berganda pada Tabel 3 dapat dibuat persamaan seperti berikut.

$$
Y=0,36+0,18 X_{1}+0,27 X_{2}+0,12 X_{3}+0,24 X_{4}+0,11 X_{5}
$$

Nilai konstanta 0,36memiliki arti jika variabel transparancy, accountability, responsibility, independency dan fairness bernilai konstan, maka variabel persepsi kualitas informasi keuangan memiliki nilai positif sebesar 0,36 . 
Variabel transparancymemilikinilai koefisiensebesar 0,18artinya transparancy berpengaruh positif pada kualitas informasi keuangan, hal ini menunjukkan bahwa transparancy berbanding lurus dengan kualitas informasi keuangan.Variabel accountability memilikinilai koefisien 0,27 artinya accountability berpengaruh positif pada kualitas informasi keuangan, hal ini menunjukkan bahwa accountability berbanding lurus dengan kualitas informasi keuangan. Variabel responsibility memilikinilai koefisien 0,12 artinya responsibilityberpengaruh positif pada kualitas informasi keuangan, hal ini menunjukkan bahwa responsibility berbanding lurus dengan kualitas informasi keuangan.Variabel independency memilikinilai koefisien0,24 artinya independencyberpengaruh positif pada kualitas informasi keuangan, hal ini menunjukkan bahwa independency berbanding lurus dengan kualitas informasi keuangan. Variabel fairnessmemilikinilai koefisien0,11 artinya fairness berpengaruh positif pada kualitas informasi keuangan, hal ini menunjukkan bahwa fairness berbanding lurus dengan kualitas informasi keuangan.

Hasil uji kelayakan model (Uji F) menunjukkan signifikan F0,00 lebih kecil dari 0,05 ini berarti model yang digunakan pada penelitian ini adalah layak.Nilai koefisien determinasi $\left(\mathrm{R}^{2}\right)$ menunjukkan seberapa jauh kemampuan variabel independen dalam menerangkan variasi variabel dependen. Tabel 3 menyajikan bahwa nilai adjusted $\mathrm{R}^{2}$ adalah 0,84 artinya bahwa 84 persendari variabel independen,yaitutransparancy, accountability, responsibility, independency dan fairnessmampu menerangkan variasi variabel dependen, yaitu 
kualitas informasi keuangan, sedangkan sisanya 16 persen dijelaskan oleh faktor lain yang tidak dimasukkan ke dalam model.

Hipotesis $1\left(\mathrm{H}_{1}\right)$ menyatakan bahwa prinsip transparancy berpengaruh positif pada kualitas informasi keuangan PDAM Kabupaten Buleleng. Hasil analisis menunjukkan bahwa semakin transparan perusahaan dalam menggungkapan informasi, artinya dapat meningkatkan kepercayaan stakeholders terhadap perusahaan sehingga akan meningkatkan kualitas informasi keuangan perusahaan. Teori keagenan (agency theory) mengatakan bahwa agen lebih banyak tahu tentang informasi perusahaan, maka untuk menghindari terjadinya asimetri informasi diperlukan adanya keterbukaan informasi. Hasil penelitian ini sejalan dengan Taufan (2016), variabel transparansi berpengaruh positif terhadap kualitas laporan keuangan pemda Bandung. Berbeda dengan hasil penelitian Mahaendrayasa (2017) bahwa prinsip transparancy tidak berpengaruh pada kinerja keuangan LPD di Kota Denpasar, karena kinerja keuangan yang dicapai sudah optimal.

Hipotesis $2\left(\mathrm{H}_{2}\right)$ menyatakan bahwa prinsip accountability berpengaruh positif pada kualitas informasi keuangan PDAM Kabupaten Buleleng. Hasil analisis menunjukkan bahwa semakin jelas penerapan wewenang, hak, kewajiban serta tanggung jawab dalam perusahaan, artinya dapat meningkatkan kualitas informasi keuangan perusahaan. Dalam teori keagenan, principaldan agentmemiliki kepentingan yang berbeda, sehingga manajemen wajib mempertanggungjawabkanatas perintah yang diberikan oleh pemilik perusahaan. Agen akan bertanggung jawab atas perintah yang diberikan jika prinsipal sebagai 
pemberi perintah mampu memberi tugas, wewenang secara jelas dan memperhatikan hak agen. Maka dari itu agen mampu melaksanakan tugas dengan baik, sehingga menghasilkan kualitas informasi keuangan yang baik.Hasil penelitian ini sejalan dengan Taufan (2016) bahwa akuntabilitas berpengaruh positif terhadap kualitas laporan keuangan pemda Bandung.

Hipotesis $3\left(\mathrm{H}_{3}\right)$ menyatakan bahwa prinsip responsibility berpengaruh positif pada kualitas informasi keuangan PDAM Kabupaten Buleleng. Hasil analisis menunjukkan bahwa semakin patuh organ perusahaan terhadap peraturan perundangan serta peraturan perusahaan artinya dalam melaksanakan tanggung jawab atas keuangan perusahaan harus dapat memberikan informasi yang sesuai dengan harapan stakeholders, sehingga responsibility mampu meningkatkan kualitas informasi keuangan PDAM Kabupaten Buleleng. Teori stewardship menjelaskan bahwa agen bertindak sesuai keinginan prinsipal untuk mencapai tujuan organisasi, sehingga dikatakan agen akan mematuhi dan bertanggungjawab atas peraturan perusahaan demi mencapai tujuan bersama, maka dari itu akan meningkatkan kualitas informasi keuangan perusahaan.Hasil penelitian ini didukung dengan penelitian Noviolanita (2015) yaitu penerapan prinsip-prinsip GCGberpengaruh pada kualitas laporan keuangan PT PLN (Persero) distribusi Jawa Barat dan Banten. Berbeda dengan hasil penelitian Mahaendrayasa (2017) yang mengatakan prinsip responsibility tidak berpengaruh pada LPD Kota Denpasar, karena kinerja keuangan yang dicapai sudah optimal.

Hipotesis $4\left(\mathrm{H}_{4}\right)$ menyatakan bahwa prinsip independency berpengaruh positif pada kualitas informasi keuangan PDAM Kabupaten Buleleng. Hasil 
analisis menunjukkan bahwa semakin independen perusahaan dalam mengelola perusahaan, artinya perusahaan tidak terdominasi dengan kepentingan pihak manapun, sehingga akan meningkatkan kualiatas informasi keuangan perusahaan. Teori keagenan menjelaskan bahwa perbedaan kepentingan antara prinsipal dengan agen akan menimbulkan adanya asimetri informasi, hal ini dapat diminimalisir jika agen independen terhadap tanggung jawabnya dengan tidak mudah terpengaruh dari pihak manapun, maka agen sebagai pengelola perusahaan akan berusaha untuk meningkatkan kualitas informasi keuangan perusahaan. Selain itu teori stewardship juga mendukung hasil penelitian dimana kepentingan bersama dijadikan dasar dari tindakan manajer.

Hipotesis $5\left(\mathrm{H}_{5}\right)$ menyatakan bahwa prinsip fairness berpengaruh positif pada kualitas informasi keuangan PDAM Kabupaten Buleleng. Hasil analisis menunjukkan bahwa dalam mengelola usahanya perusahaan harus berlandasakan kewajaran dan kesetaraan, maka kualitas informasi keuangan akan meningkat. Teori keagenan menjelaskan bahwa prinsipal sebagai pemilik akan memberi perintah kepada agen, dalam hal ini prinsipal harus mampu memperlakukan agen dengan setara dan wajar agar agen menyampaikan informasi perusahaan secara benar sesuai dengan kondisi perusahaan agar tidak terjadi asimetri informasi. Penelitian ini sejalan dengan Noviolanita (2015) pada hasil penelitiannya yaitu penerapan prinsip-prinsip GCG berpengaruh positif pada kualitas laporan keuangan PT PLN (Persero) distribusi Jawa Barat dan Banten. 


\section{SIMPULAN}

Berdasarkan pembahasan pengaruh penerapan prinsip good corporate governance pada persepsi kualitas informasi keuangan PDAM Kabupaten Buleleng, maka dapat ditarik simpulan bahwa prinsip transparancy berpengaruh positif pada kualitas informasi keuangan PDAM Kabupaten Buleleng,prinsip accountability berpengaruh positif pada kualitas informasi keuangan PDAM Kabupaten Buleleng, prinsip responsibility berpengaruh positif pada kualitas informasi keuangan PDAM Kabupaten Buleleng, prinsip independency berpengaruh positif pada kualitas informasi keuangan PDAM Kabupaten Buleleng dan prinsip fairness berpengaruh positif pada kualitas informasi keuangan PDAM Kabupaten Buleleng.

Berdasarkan hasil penelitian dan simpulan maka saran yang dapat disampaikan yaitu dengan mempertimbangkan pengaruh penerapan prinsip good corporate governancedapat mempengaruhi kualitas informasi keuangan PDAM Kabupaten Buleleng,diharapkan agar pemerintah mempertimbangkan untuk membuat regulasi terkait dengan penerapan prinsip good corporate governancedi BUMD lainnya sehingga akan memberi dampak pada kualitas informasi keuangan. Kemudian besarnya nilai Adjusted $R$ Square sebesar 84 persen artinya kualitas informasi keuangan dapat dijelaskan oleh transparancy, accountability, responsibility, independency dan fairness, sedangkan sisanya sebesar 16 persen dijelaskan oleh variabel lainnya yang tidak dimasukkan ke dalam penelitian ini. Penelitian selanjutnya disarankan untuk menggunakan atau menambahkan 
variabel bebas lain seperti CSR, budaya organisasi, gaya kepemimpinan dan komitmen organisasi.

\section{REFERENSI}

Anthony, R. N. dan Govindarajan, V. 2011. Sistem Pengendalian Manajemen Edisi 12 Terjemahan. Tangerang: Karisma Publishing Group.

Araujo, Elidio De., Budiman Christiananta. 2013 Confirmatory Factor Analysis On Strategic Leadership, Corporate Culture, Good Corporate Governance And Company Performance. Part-II: Social Sciences and Humanities, 4(4).

Barrett, P. 1997. Corporate Governance and Accountability for performance. In Address To A Joint Seminar by IPAA and ASCPAs on 'Governance and the role of the senior public executive', Canberra, 27.

Brown, L. D., dan Caylor, M. L. 2004. Corporate Governance and Firm Performance. Available at SSRN 586423.

Chaarani, Hani El. 2014. The Impact Of Corporate Governance On The Performance Of Lebanese Banks. The International Journal of Business and Finance Research 8(5).

Clemente, A. G. dan Labat, B.N. (2009). Corporate Governance Mechanisms and Voluntary Disclosure. The role of independent directors in the boards of listed Spanish firms. The Spanish Association of Accounting and Management (ARCA) and the Ministry of Education INNCENOR (SEJ 2005-08644-C02-01).

Eisenhardt, Kathleen. M. 1989. Agency Theory: An Assesment and Riview. The Academy Manajement Jounal. 14(1), pp.57-74.

Fathi, J. 2013. Corporate Governance System and Quality of Financial Information.Mediterranean Journal of Sosial Sciences, 4(2), pp.129.

Financial Accounting Standards Board (FASB). 1980. "Statement of Financial Accounting Concepts No. 2: Qualitative Characteristics of Accounting Information". Stamford. Connecticut.

Haque, F., Arun, T., dan Kirkpatrick, C. 2008. Corporate Governance and Capital Markets: A Conceptual Framework. White paper, Heriot-Watt University 
Hayati, N. R., Muclis, T. I., dan Oktaviani, F. 2009. Comparison Analysis of Financial Performance on Shariah Banking (Case Study In Indonesia and Malaysia). Journal of International Business Academics Consortium Academy of Taiwan Information Systems Research college of Business National Taipe University.

Hindistari, Renitha Ratu dan IG.A.M. Asri Dwija Putri.2016. Pengaruh Penerapan Prinsip-Prinsip Good Corporate Governance Pada Kinerja Bank Perkreditan Rakyat Kabupaten Gianyar.E-Jurnal Akuntansi Universitas Udayana, 16(1), hal.101-128.

Ikatan Akuntan Indonesia (IAI). 2007. Standar Akuntansi Keuangan. Jakarta:Salemba Empat.

Jensen, Michael. C, dan Meckling, William. H. 1976. Theory of The Firm: Manajerial Behavior Agency Costs and Awnership Structure. Jurnal of Financial Economics, 3(4), pp.305-306.

Kep-117/M-MBU/2002. 2002. Keputusan menteri Badan Usaha Milik Negara tentang penerapan praktek Good Corporate Governance pada Badan Usaha Milik Negara. Jakarta: Menteri BUMN.

Komite Nasional Kebijakan Governance (KNKG). 2006. Pedoman Umum Good Corporate Governance Indonesia, Jakarta.

Mahaendrayasa, Krishna Aryastha Putu dan I G.A.M. Asri Dwija Putri. 2017. Pengaruh Penerapan Prinsip-Prinsip Good Corporate Governance Terhadap Kinerja Lembaga Pengkreditan Desa (LPD) di Kota Denpasar. E-JurnalAkuntansi Universitas Udayana.21(3), hal.970-995.

Mark, T. (2000). Surveys Reveal Investors Will Pay for Good Governance Mckinsey Quarterly Survey. World Bank and Korea's Yonsei University

Noviolanita, Clara. 2015. Pengaruh Penerapan Prinsip-Prinsip Good Corporate Governance Berpengaruh Terhadap Kualitas Laporan Keuangan PT PLN (Persero) Distribusi Jawa Barat Dan Banten. SkripsiFakultas Ekonomi Sekolah Tinggi Ilmu Ekonomi (STIE) Ekuitas: Bandung.

Oliver Hart.1995. Corporate Governance: Some Theory and Implication. The Economics Jurnal, 105(430), pp: 205-213.

Onuorah, Anastasia Chi-Chi dan Appah, Ebimobowei. 2012. Accountability and Public Sector Financial Management in Nigeria. Arabian Journal of Business and Management Review, 1(6): pp:1-17. 
Peni, Emilia, Stanley D. Smith, dan Sami Vahamaa. 2013. Bank Corporate Governance and Real Estate Lending During the Financial Crisis. JRER, $35(3)$.

Riyadi, Slamet dan Agung Yulianto. 2014. Pengaruh Pembiayanaan Bagi Hasil, Pembiayaan Jual Beli, Financing to Deposit Ratio (FDR), Non Performing Financing (NPF) Terhadap Profitabilitas Bank Umum Syariah di Indonesia. Jurnal Analisis Akuntansi, 3(4), hal.466-474.

Sari, Yessi Amanda dan Rima Rachmawati. 2014. Pengaruh Penerapan Good Corporate Governance terhadap Informasi Kinerja Keuangan pada PDAM Tirta Jati Kabupaten Cirebon, PDAM Tirta Dharma Kota Cirebon, PDAM Tirta Medal Kabupaten Sumedang, dan PDAM Tirta Kamuning Kabupaten Kuningan. Skripsi Sarjana Jurusan Akuntansi pada Fakultas Ekonomi Universitas Widyatama, Bandung.

Taufan,Muhamad Iqbal. 2016. Pengaruh Transparansi dan Akuntabilitas Terhadap Kualitas Laporan Keuangan Pemerintah Daerah Kota Bandung. SkripsiFakultas Ekonomi Universitas Widyatama: Bandung.

Todorovic, Igor dan Zdravko Todorovic. 2012. Compliance With Modern Legislations Of Corporate Governance And Its Implementation In Companies. Montenegrin Journal Of Economics, 8 (2).

Wijaya, I Gusti Kadek Harta Kesuma dan Made Sudarma. Faktor-Faktor yang Mempengaruhi Pergantian Kantor Akuntan Publik pada Perusahaan Manufaktur di Indonesia. SkripsiFEB Universitas Brawijaya:Malang.

YPPMI Institut dan FCGI. 2002. Good Corporate Governance dalam Konsep dan Implementasi Perusahaan Publik dan Korporasi Indonesia. YPPMI Sinergy Comunication. 